\title{
Analysis of Dividend Yield and Stock Return in Nairobi Securities Exchange in Kenya
}

\author{
Simon Oluoch Ondiwa* $\quad$ Dr. David Oima Dr. Fredrick Aila \\ School of Business and Economics, Maseno University Private Bag Maseno, Kenya
}

\begin{abstract}
Capital Markets have been reflecting erratic performance coupled with volatility globally, regionally and in domestic market. According to Capital market 2030, the future of equity capital markets report (2018), United States of America outperformed her major emerging markets. The combined United State of American's Domestic market caps total US\$30.4 trillion; total mainland China and Hong Kong was US\$10.1 trillion. In 2011, it was US\$ 15.6 trillion and US\$ 5.7 trillion respectively. United States of America Securities exchanges are now three times the size of their Chinese counterparts compared with 2.7 times in 2011. The growth in the US market has outstripped expectations, while the growth of China and other emerging markets has lagged. Despite Capital markets performance in USA, indices showed volatility in performance of the S\&P 500 and the Hang Seng relative to FTSE/JSE, Africa all All-share index and S\&P Pan Africa with the FTSE 100 showing relative stability. Among other factors, volatility could be attributed to trade tariffs imposed by the US, primarily impacting China, continuing political. In Kenya, 20 shares Index which is used as a proxy of stock return in this study performed dismally in 2011 as compared to 2012 (Kenya Economic report, 2011). The total number of shares traded went down in 2014 and NSE 20 Share Index declined in the fourth quarter of 2016 (The Kenya economic survey, 2016). With volatility witnessed between 2009 and 2018, analysis of relationship between dividend yield and stock return is imperative. This study used quarterly data between 2009 and 2018. The study is a time series study and research design used is correlation. The data was transformed by converting them to their natural logarithms and then differenced to their first differences. After the first differences, the data became stationary. Results revealed that dividend yield has an inverse significant relationship on Nairobi Securities Exchange 20 Share Index, $(\mathrm{t}=-2.91, \mathrm{p}=0.006)$. Results of this study are useful to policy makers, investors, regulators and finance analyst.
\end{abstract}

Keywords: Dividend yield, NSE-20 Share Index, Stock Return, emerging markets, Volatility, Capital markets.

DOI: $10.7176 /$ RJFA/12-8-01

Publication date: April $30^{\text {th }} 2021$

\section{Introduction}

This study is anchored on both dividend irrelevant theory and dividend relevant theory. The dividend irrelevance theorem was developed by Modigliani \& Miller (1961) who stated that dividend policy has no significant effect on a firm's share price or cost of capital. They argued that, as the amount of debt financing increases, the marginal cost of capital decreases, dividends could not be used to enhance a firm's value as there would almost not be any equity capital in the firm. Modigliani \& Miller (1961) model holds that dividend policy of the firm is irrelevant since it does not affect the wealth of the shareholders. Furthermore, they argued that the value of the firm depends on the firms earning which is as a result of its investment policy.

According Pandey (2005), Modigliani and Miller dividend theory had a number of unrealistic assumptions; the firm operates in perfect capital markets where investors behave rationally and that information is freely available to all, transaction and floatation costs do not exist. Perfect capital markets also means that no investor is large enough to affect the market price of shares, secondly, taxes do not exist or there is no difference in the tax rate applicable to the capital gains and dividends; this means that investors value a shilling of dividend as much as a shilling of capital gain, thirdly, the firm has a fixed investment policy, the fourth assumption is that risk of uncertainty does not exist, that is, investors are able to forecast future prices and dividend with certainty and one discount rate is appropriate for all securities and all time periods.

Modigliani \& Miller (1961) proposition hold that with well-functioning markets (and neutral taxes) and rational investors, who can "undo" the corporate financial structure by holding positive or negative amounts of debt, the market value of the firm, debt plus equity depends only on the income stream generated by its assets. Furthermore, the value of the firm should not be affected by the share of debt in its financial structure or by what will be done with the returns paid out as dividends or reinvested profitably. Separately Modigliani \& Miller (1980) opined that a firm that pays dividends will have to raise funds externally to finance its investments. Modigliani and Miller proposition that dividend policy does not affect the wealth of shareholders means that when a firm pays dividends the advantage is offset by external financing hence terminal value of the share decline when dividends are paid; the wealth of shareholders dividend and terminal price remains unchanged. The present value per share after dividends and external financing is equal to the present value per share before the payouts of dividends and retention of earnings. 
Empirical studies reviewed however revealed mixed results, for instance, in India, Kamini \& Malhotra (2013) sought to study determinants of stock prices. The study was analytical in nature using stock price and secondary data for purposes of empirical evaluation of stock price and explanatory variables. Sample population was of National Stock Exchange 100 companies, the study deployed correlation and linear multiple regression models to measure the effect of the independent variables on dependent variables. To avoid the problem of multi-colinearity, backward elimination procedure of regression was used. The results revealed that earnings per share have a significant positive association with firm's stock price while dividend yield has a significant inverse association with the market price of the firm's stock. The study however did not use time series analysis and it was not undertaken at industry level.

In South Africa, Nicol (2013) sought to study dividend policy and wealth maximization. The study combined both explanatory design and descriptive design. The study used dividend yield as an indicator of dividend size. Dividend yield was calculated on a monthly basis. The results indicated that the level of dividend yield appears to influence returns positively. During the bear markets, no significant difference in abnormal risk adjusted returns was observed for the portfolios with highest dividend yield. However, in bull markets, the return for portfolios with the highest dividend yield was more than double the result for more dividend payers. His study used dividend distributions measured in dividend yield during bull and bear market and monthly risk adjusted share return measured for the various dividend yield groups. He opined that dividend yield relates the dividend amount paid in relation to the share price and that many investors use dividend yield as a measure of risk and as an investment screen.

In United States of America Kang et al., (2019) did a study on dividend yield, stock returns and reputation and they revealed conflicting results from the present study. They used panel regression. Their philosophy was qualitative research design. After controlling the reputation effect and other relevant variables, the study revealed that there is positive relationship between dividend yields and stock return. Their study concluded that the relationship between dividend yields and stock returns is unresolved issue in finance, as the empirical evidence is mixed. Furthermore, the study concluded that one year is not enough to build a dividend reputation. Their study did not use quantitative paradigm, their study did also not use time series with quarterly data and lastly, their study was done in the United States of America. These methodological differences and study area could be the reason for conflicting results.

At Stellenbosch University Pierre (2012) studied influence of dividend yield and dividend stability on share return. He allocated firms to portfolios based on dividend yield and dividend stability, and risk -adjusted abnormal returns for these portfolios were estimated. The study was anchored on quantitative paradigm. Results indicated that share returns were influenced not only by dividend payment levels, but also by stability of those payments over time. The nature of a firm's dividend decision could therefore have an effect on its share returns. This study deviates from other reviewed studies by incorporating the aspect of dividend stability; the study did not use time series analysis. The study was not done in Kenya. These differences could have been the cause of these conflicting results.

Most of the studies reviewed on the relationship between dividend policy and stock return used convenience sampling; judgmental sampling, random sampling and purposive sampling such sampling methods are not robust enough to conclusively draw inferences. Furthermore, the studies were anchored on different research philosophies; some used quantitative paradigm, others used qualitative paradigm while the rest used pragmatic paradigm. Majority of the studies were conducted in developed countries where securities exchanges are more developed with few studies from developing countries like Kenya. Most of the studies reviewed also used panel data as opposed to the current study which used time series analysis. None of the studies reviewed was done at industry level hence it is not clear how the results could have been assuming the studies were done at industry level. From the literature reviewed, no known study has been conducted to establish the relationship dividend policy and stock return in Nairobi Securities Exchange using time series analysis at industry level.

\section{Methods}

Vibha \& Walsh (2019) reported that research design is a structure of research, that is, it is the "Glue" that holds all the elements together; it is a plan of the proposed research work. According to Lincoln et al., (2011) the term paradigm is used to refer to philosophical assumptions or to the basic set of beliefs that guide the actions and define the worldview of the researcher; paradigms are conceptual and practical "tools" that are used to solve specific research problems. According to Philips (1987) and Creswell (1994), a study can follow a qualitative and/or a quantitative paradigm. The quantitative paradigm is termed as the traditional, positivist, experimental, or empiricist paradigm. It is based on the empiricist tradition. In contrast, the qualitative paradigm is termed as the constructivist, naturalistic, interpretive; post - positivist, experimental or postmodern perspective (Smith, 1983). Furthermore, Creswell \& Clark (2011) reports that constructivism is associated with qualitative methods and literary and informal rhetoric in which the researcher relies as much as possible on the participants view and develops subjective meanings of the phenomena. Constructivist research is shaped from the bottom up, that is, 
from individual participants to broad patterns and ultimately broad understandings (Creswell \& Clark, 2011).

Goles \& Hirschheim (2000) reported that besides the two common paradigms is pragmatism; pragmatists believe that the process of acquiring knowledge is a continuum rather than two opposing and mutually exclusive poles of either objectivity or subjectivity. According to Maxcy (2003) pragmatism finds its philosophical foundation in the historical contribution of the philosophy; it embraces plurality of methods. As a paradigm, pragmatism is based on the proposition that the researchers should use the philosophical and or methodological approach that works best for the particular research problem that is being investigated (Tashakkori \& Teddlie, 1998); it is associated with mix methods or multiple methods, where focus is on the consequences of research rather than on the methods; it may employ both formal or informal rhetoric (Creswell \& Clark, 2011).

Oberiri (2017) asserted that research deal with quantifying and analyzing variables in order to get results; it involves the utilization and analysis of numerical data using specific statistical techniques. He opined that quantitative methods can be categorized into survey research, correlational research, experimental research and causal- comparative research. The study adopted correlation research design whereby it begun with the selection of the topic and a paradigm (Robson, 1993). This research technique is used to relate two or more variables and allow predictions of outcomes based on causative relationships between the variables (Zeitun \& Tian, 2007; Ebaid, 2009). The present study adopted quantitative research designs because of the variables under study were reported in numerical form; this is so based on the research objectives.

\subsection{Study Area}

The study was carried out in the Nairobi Securities Exchange (NSE) in Nairobi City. Nairobi is Kenya's capital, premier city, and one of Africa's most important cities. It has an estimated population of 3.5 million and a land area of 695 square kilometers. The recently created Nairobi Metropolitan Region has an area of 32,000 square kilometers and an estimated population of 6.65 million people (2009 population census). The city lies between 1,600 and 1,850 meters above sea level on the southeastern edge of Kenya's agricultural heartland at 1816'S latitude and 36848 'E longitude; its high elevation gives the city a temperate climate despite its close proximity to the equator. Its average density of 4,515 people per square kilometer is the highest in the country, followed by that of Mombasa (4,292 people per square kilometer), Kenya's second largest city, whose 2009 population was 939,370 (Commission of Revenue Allocation 2011). The western side of the city is higher, cooler, and welldrained, whereas the eastern half is lower, hotter, and swampy.

\subsection{Target Population}

Mugenda \& Mugenda (2003) define population as the entire group a researcher is interested in or a group about which the researcher wishes to draw conclusions. The study population was all the 65 listed firms in Nairobi Securities Exchange. The Nairobi Securities Exchange draws data from listed firms and reports on ratios and indices. The Nairobi Securities Exchange (NSE) is a leading African Exchange, based in Kenya; founded in 1954, NSE has six decade heritage in listing equity and debt securities. It offers a world class trading facility for local and international investors looking to gain exposure to Kenya and Africa's economic growth (Nairobi Securities Exchange)

\subsection{Sampling Size and Techniques}

The study included all the 65 listed companies at industry level. Mlambo \& Biekpe (2001) in South Africa studied African Securities markets and opined that there were only seven stock markets in Africa before 1988 and they increased to 20 in 2000; they noted that most African stock markets still have restrictive capital flow regulations on the remittance of capital, capital gains, dividends, interest payments, returns and other related earnings hence constraining foreign investments. From the foregoing, and with knowledge that regulations in various countries are not the same, studying more than one securities Exchange my result into biased conclusions that may not be generalized. The present study therefore chooses to study only Nairobi Securities Exchange due to logistics, time and financial constraints in addition to the desired objective of the research. Quarterly data for study variables were analyzed during the study period. The total quarters were 40 and total variables were 8 , this resulted to 320 data points. The data were organized in a table form where variables were arranged in columns and quarters and years are arranged in rows.

\subsection{Data collection Methods}

The data collection stage of empirical research involves several choices such as type of research design, what sampling procedures are implemented, whether to use control variables and which ones in particular, and how to manage missing data (Herman et al., 2019). Some of the considerations in data collection stage are the cost of data collection, practicality of the proposed method of data collection, if samples are used, the samples must be representative of the population, the various errors and biases which may lead to wrong conclusion must be minimized, or if possible avoided (Chinelo, 2016). 


\subsection{Sources of Data}

The study employed secondary data with quarterly dividend yield and quarterly NSE 20 share index for the ten year study period. Given that Nairobi Securities Exchange is a reliable and reputable body in the country, the data sourced from it are expected to be accurate and authentic.

\subsection{Data collection procedures}

Data related to dividend yield and NSE 20 Share Index was bought from Nairobi Securities Exchange. These data were provided by Nairobi Securities Staff in charge of preparation and dissemination of data. After payment for the data, they were sent via mail. The data had already been organized in quarterly data for the study period. After sourcing data from Nairobi Securities exchange, data was organized and converted to quarterly data and presented in tabular form.

\subsection{Reliability Tests}

Reliability refers to the extent to which an experiment, test or any measuring procedure yields the same results on repeated trials. Reliability test was done using coefficient correlation by examining the internal consistency and using three steps in evaluating secondary data proposed by (Saunders, Lewis \& Thornhill, 2007). First by assessing suitability of the data in meeting research objectives, secondly, by checking whether the data generates the measures required in this study and finally the credibility of the source in terms of how the data was collected, by whom and how checks were ascertained. Reliability of data in this study was done through expert opinion from an expert in the field of finance.

\subsection{Validity Test}

The validity of a measure is defined as the extent to which a construct or a set of measures correctly represents the concept of the study and the degree to which it is free from any systematic or non-random error (Nunnaly, 1978). In the prssent study validity was assesed by performing diagnostic statistics. First variables were converted into their natural logarithms before converting them to their first lags through differencing. Stationarity test was then performed and all of them were found to be stationary. Correlation analysis was performed and independent variable had significant linear relationship with dependent variable. Multicollinearity test revealed that there was no multicollinearity issues with the variables under study. Lastly, autocorrelation test revealed that there was no autocorrelation among the variables.

\subsection{Data Analysis and Presentation}

The data were analyzed by use of quantitative approaches such as descriptive statistics, time series analysis, multiple and linear regression. Autoregressive Integrated Moving Average ARIMA (p, d, q) was used for data transformation.

\subsection{Data Transformation and ARIMA $(p, d, q)$ Model}

The ARIMA (p, d, q) model is a modification of the ARMA models arrived at by transforming the time series data to stationary. It became popular in the 1970's among academics, Cooper (1972) shows that ARIMA could outperform the large and complex econometric models, popular at that time in many situations. If time series $d$ is differentiated, then the model becomes stationary (Ransang \& Titida, 2006). Applying ARMA ( $p, q)$ to it, we say the original time series has been transformed to stationarity and it is refers to as autoregressive moving average $(p, d, q)$ where $p$ is the number of autoregressive terms, $d$ is the number of non-seasonal differences and $q$ is the number of lagged forecasts errors in the prediction equation. Stationarity in the model can be detected by the use of the autocorrelation function graph (ACF). If a graph of the time series values either cuts off or dies down fairly quickly, then the time series should be considered stationary. If however, the graph of the ACF dies down extremely slowly, then the time series should be considered non-stationary. If the original time series is stationary, $d=0$ and ARIMA (p, d, q) model reduces to ARMA model.

\subsection{Model Specification}

A model developed to establish relation between dividend yield (X's) and stock Return (Y) in Nairobi Securities Exchange.

$\mathrm{Y}_{\mathrm{t}-1}=\beta_{0}++\beta_{1} X_{1 t-1}+\mathrm{e}_{\mathrm{t}-1 \ldots \ldots \ldots \ldots \ldots \ldots \ldots \ldots \ldots \ldots \ldots \ldots}$

Where:

$\mathrm{Y}_{\mathrm{t}-1}=$ lag one of natural logarithm of NSE 20 Share Index at quarter $\mathrm{t}$,

$\mathrm{B}_{1}=$ Constant representing the coefficient of the first difference of natural logarithm of dividend yield (DY),

$\mathrm{X}_{1 \mathrm{t}-1}=$ lag one of natural logarithm of dividend yield at quarter $\mathrm{t}$,

$\mathrm{e}_{\mathrm{t}}=$ The error term at time $\mathrm{t}$ 


\subsection{Stationarity Test}

When using time series data, it is important to ensure that the data is stationary before proceeding with analysis (Granger \& Newbold, 1974, Gujarati, 2006). Most researchers employ the first difference approach, mainly as a result of Nelson and Plossers' (1982) work which they argued that many macroeconomic time series use difference stationarity and not trend stationary. Granger \& Newbold (1974) refer to results obtained from regressions that contain non-stationary data as spurious regression results which are empirical results with highR squared estimates and very low Durbin-Watson statistics, which can be regarded as excellent results but are of no use (Gujarati, 2006). Figure 1 below reveal that dividend yield was stationary.

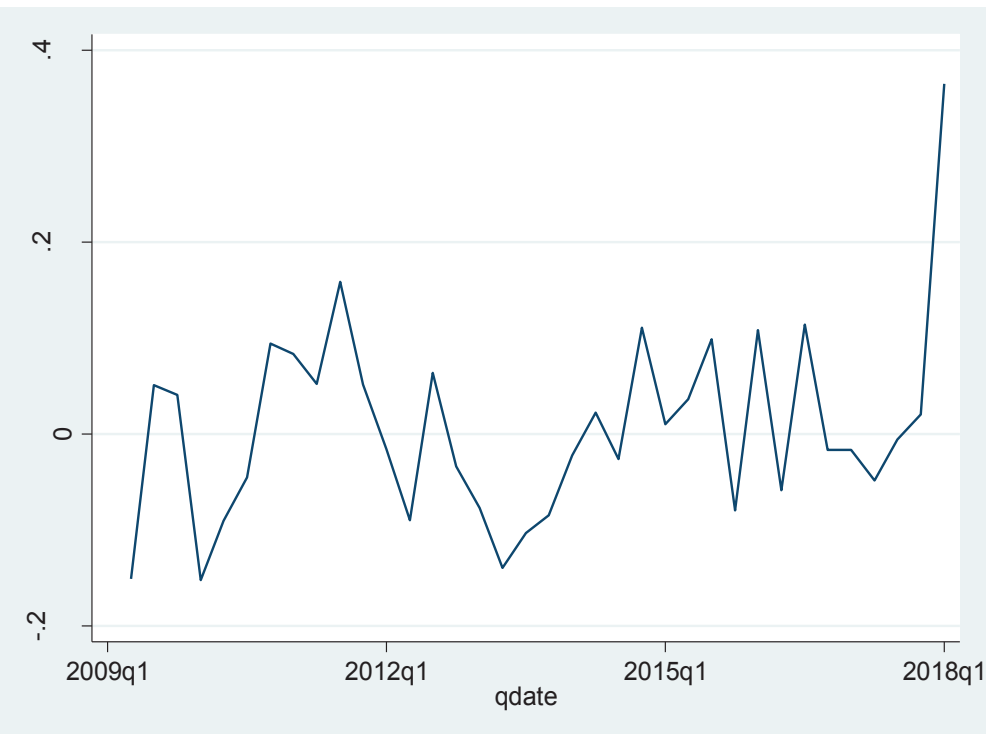

Figure 1: Stationarity test for Dividend Yield

Source: Field Data 2019

\subsection{Autocorrelation Test}

Many parametric statistical procedures assume that the errors of the models used in the analysis are independent of one another, that is, the errors are not correlated. When this assumption is not met in the context of time-series research designs, the errors are said to be auto correlated or dependent. Because time-series designs involve the collection of data from a single participant at many points in time rather than from many participants at one point in time, the assumption of independent errors inherent in many parametric statistical analyses may not be met. When this occurs, the outcome of these analyses and the conclusions drawn from them are likely to be misleading unless some corrective action is taken (Bradley \& Sean, 2006).

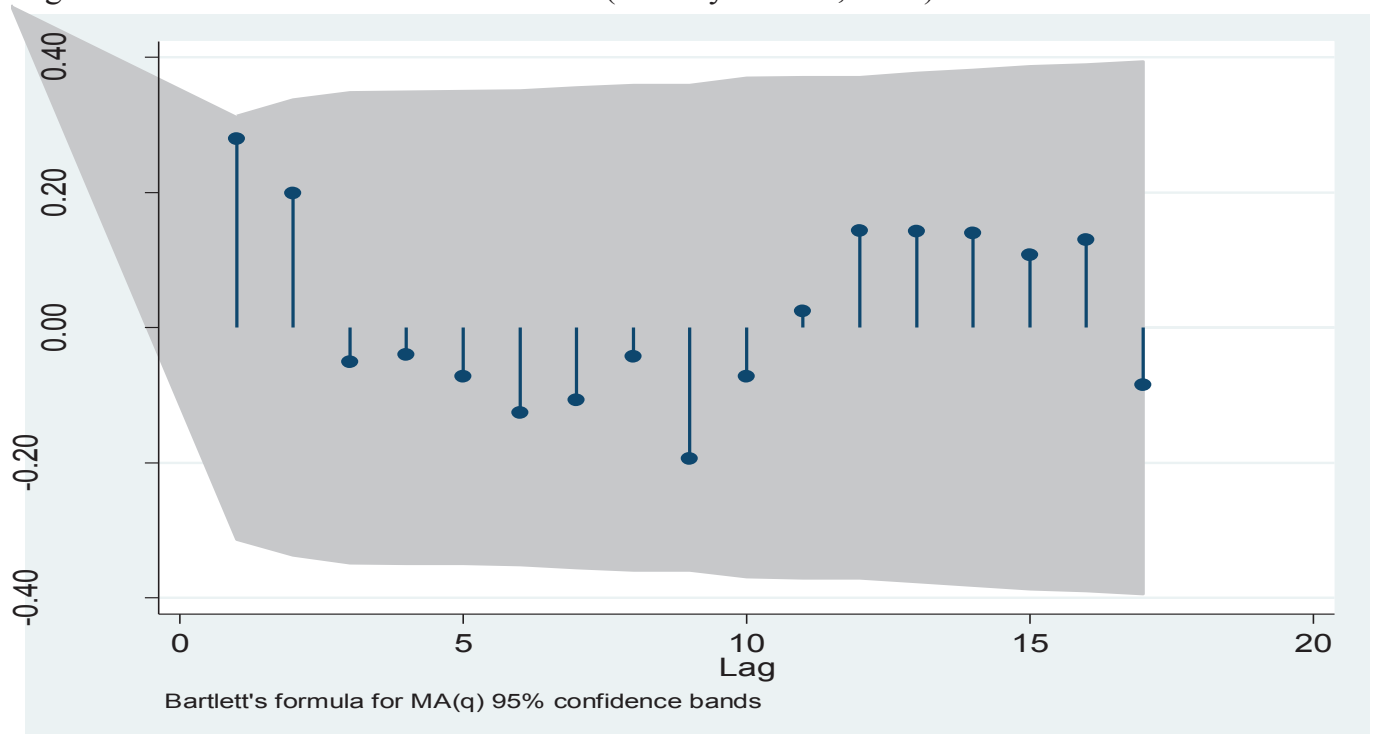

Figure 2 Autocorrelation of Dividend Yield Source: Field Data 2019 


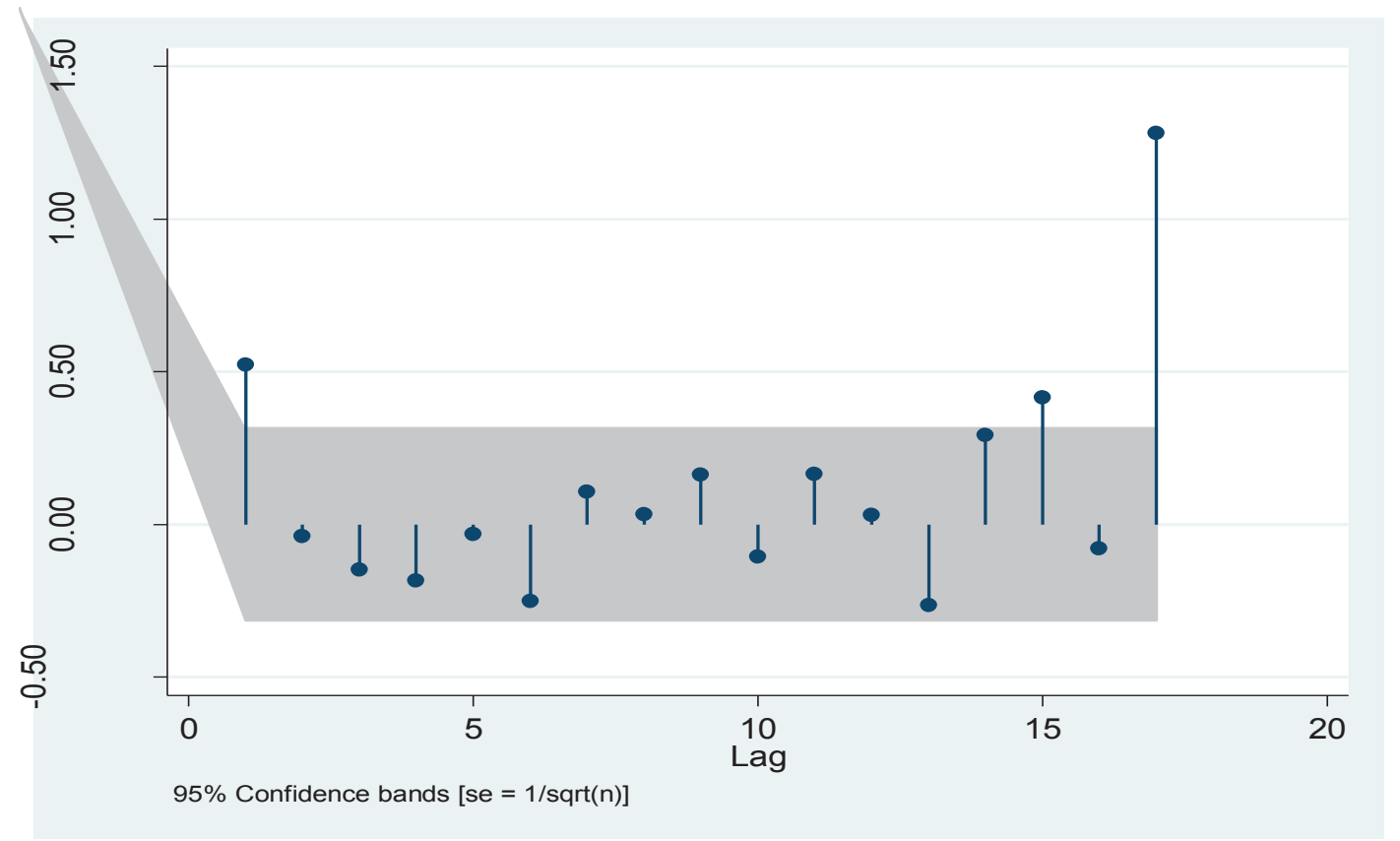

Figure 3: Autocorrelation of NSE 20 Share Index Source: Field Data 2019

\subsection{Normality Test}

Das \& Imon (2016) observed that in statistics, it is conventional to assume that the observations are normal. The entire statistical framework is grounded on this assumption and if this assumption is violated the inference breaks down. It is therefore essential to assess normality of a data before any formal statistical analysis. Otherwise we might draw erroneous inference and wrong conclusions. Normality can be assessed both visually and through normality tests. Before analysis was done, the data were tested for normality. Figure 4 and 5 below reveal that the data was normal hence was fit to be used for analysis and inferences.

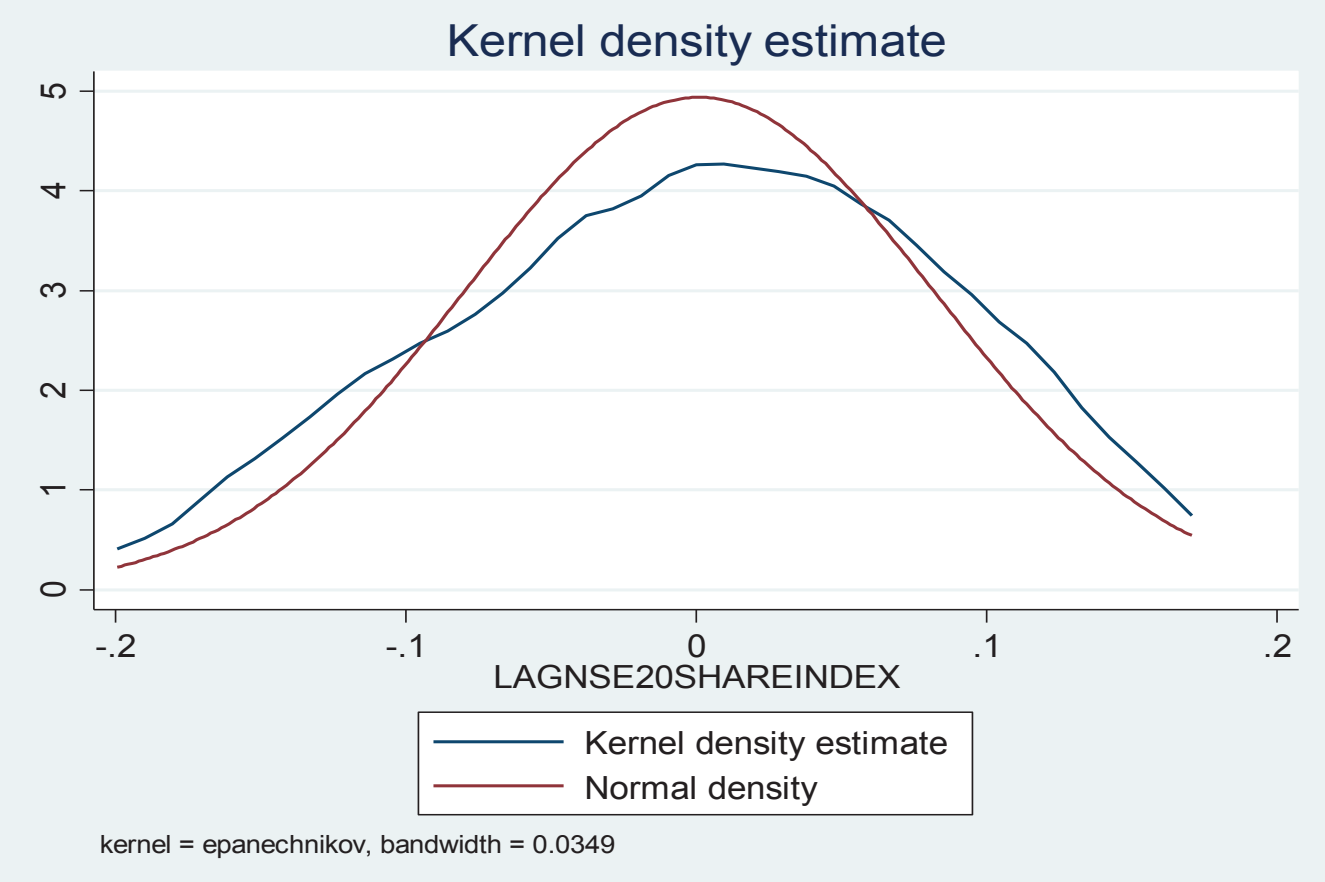

Figure 4: Normality Test of NSE 20 Share Index Source: Field Data 2019 


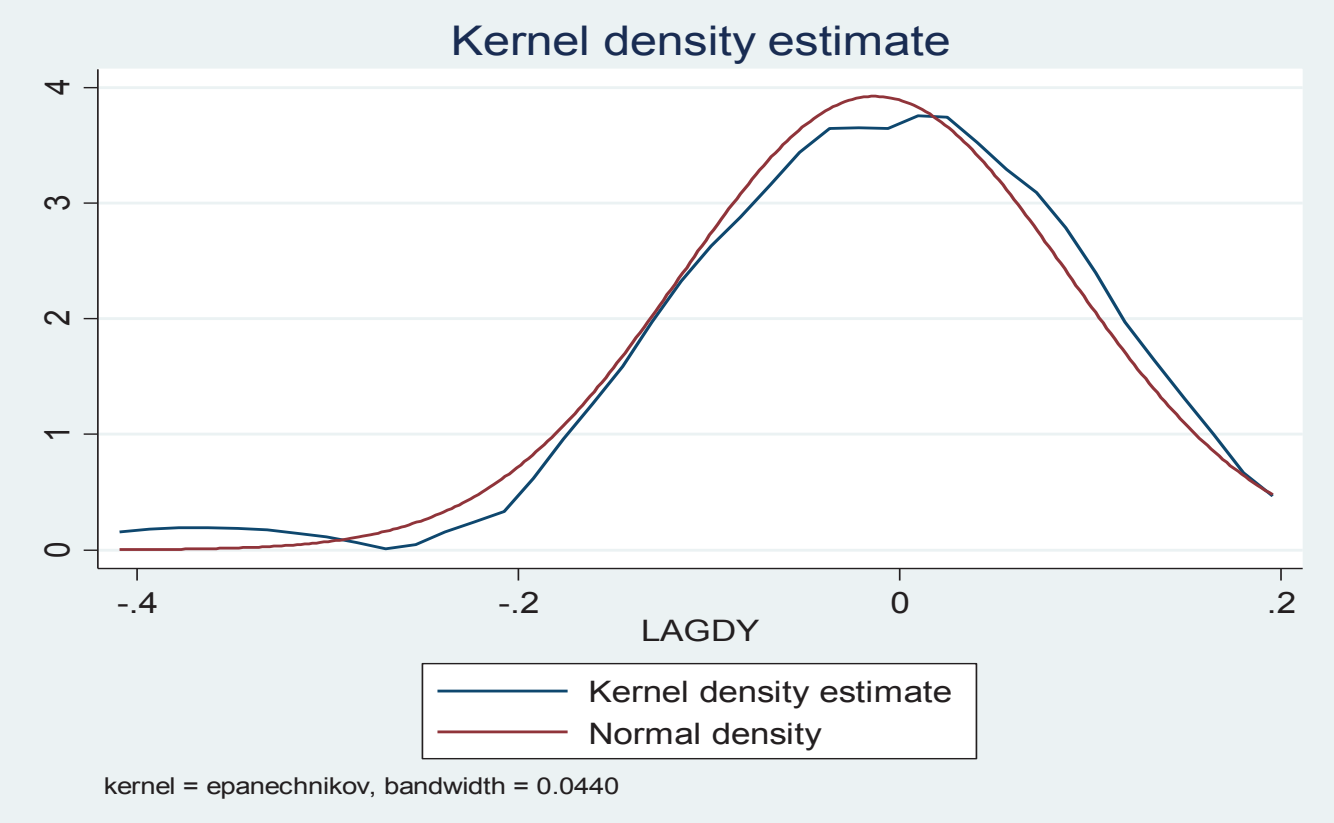

Figure 5: Normality Test of Dividend Yield

Source: Field Data 2019

\subsection{Results}

3.1. Descriptive Statistics

Table 1: Descriptive statistics.

\begin{tabular}{lrrrrrrr}
\hline Variable & Obs & Mean & Std. Dev & Min & Max & Skewness & Kurtosis \\
\hline Dividend Yield & 40 & 1.277236 & 0.2209425 & 0.9707789 & 1.882514 & 1.141183 & 4.26257 \\
NSE-20 Share Index & 40 & 8.266954 & 0.1828903 & 7.939608 & 8.573505 & -0.0040621 & 1.861072 \\
\hline
\end{tabular}

NSE 20 Share Index had a mean of 8.266954 and a standard deviation of 0.1828903 with minimum values of 7.939608 and maximum value of 8.573505 and dividend yield had a mean of 1.277236, standard deviation of 0.2209425 with minimum values of 0.9707789 and maximum of 1.882514 respectively.

\subsection{Data characteristics}

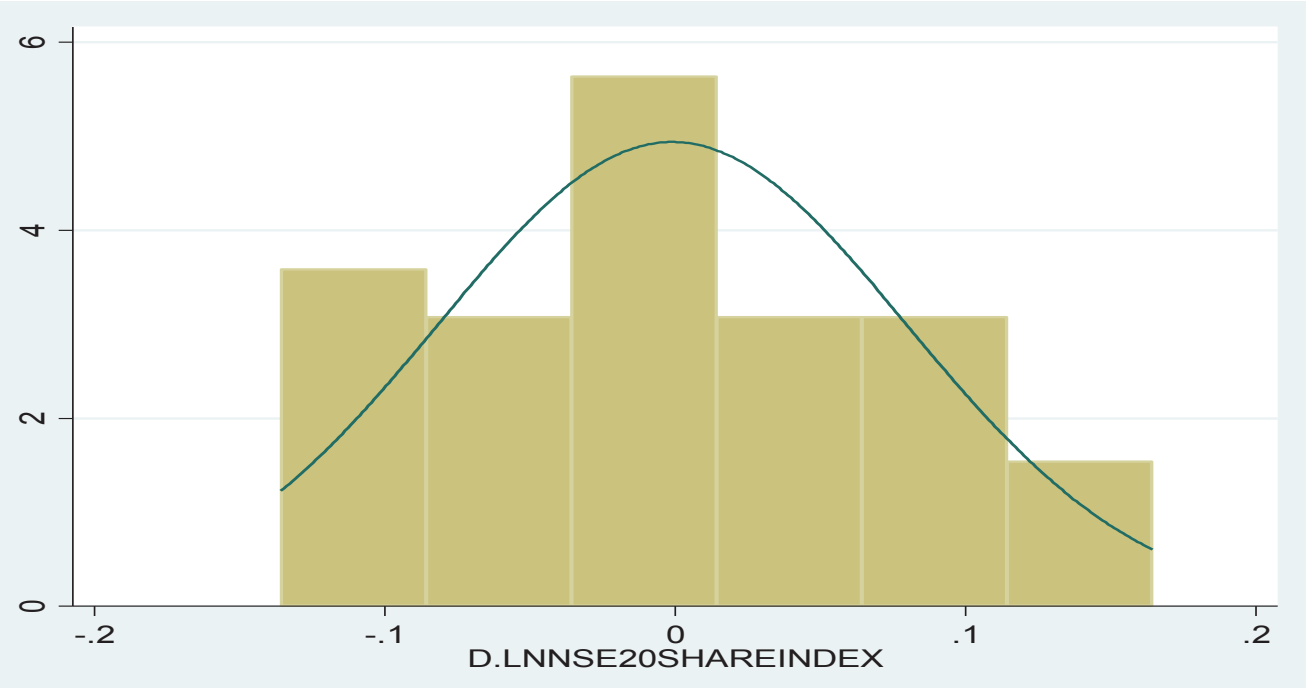

Figure 6: Histogram for first differences of natural logarithms of nse20shareindex.

$$
\text { Source: Field Data, } 2019
$$

DY had a mean of 1.277236 and a standard deviation of 0.2209425 with minimum value of 0.9707789 and maximum value of 1.882514 . 


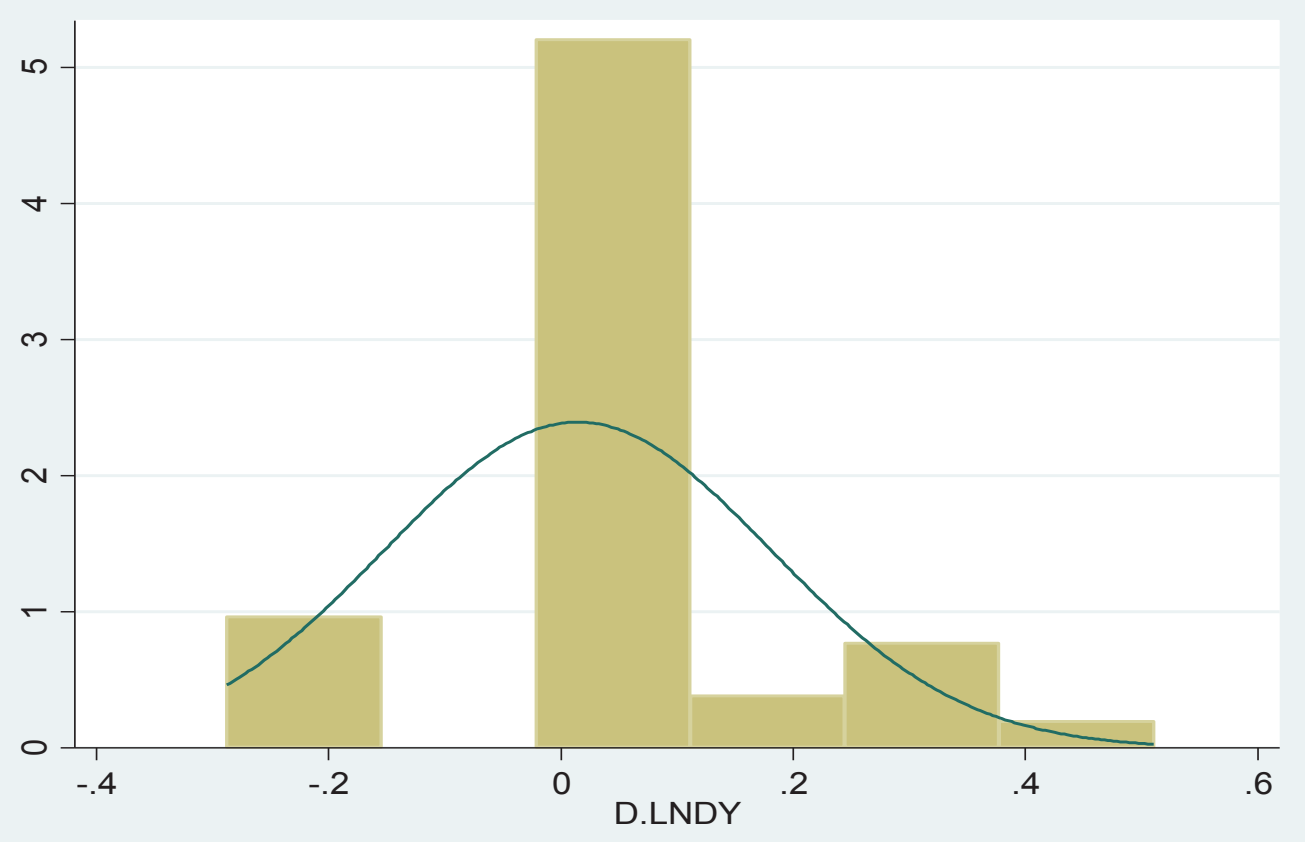

Figure 7: Histogram for first differences of natural logarithms of dividend yield. Source: Field Data, 2019.

Dividend yield dipped in 2009 and 2010 (between quarters 4 to 8) and peaked between 2011, 2012 and 2016 before peaking in 2017 and 2018.

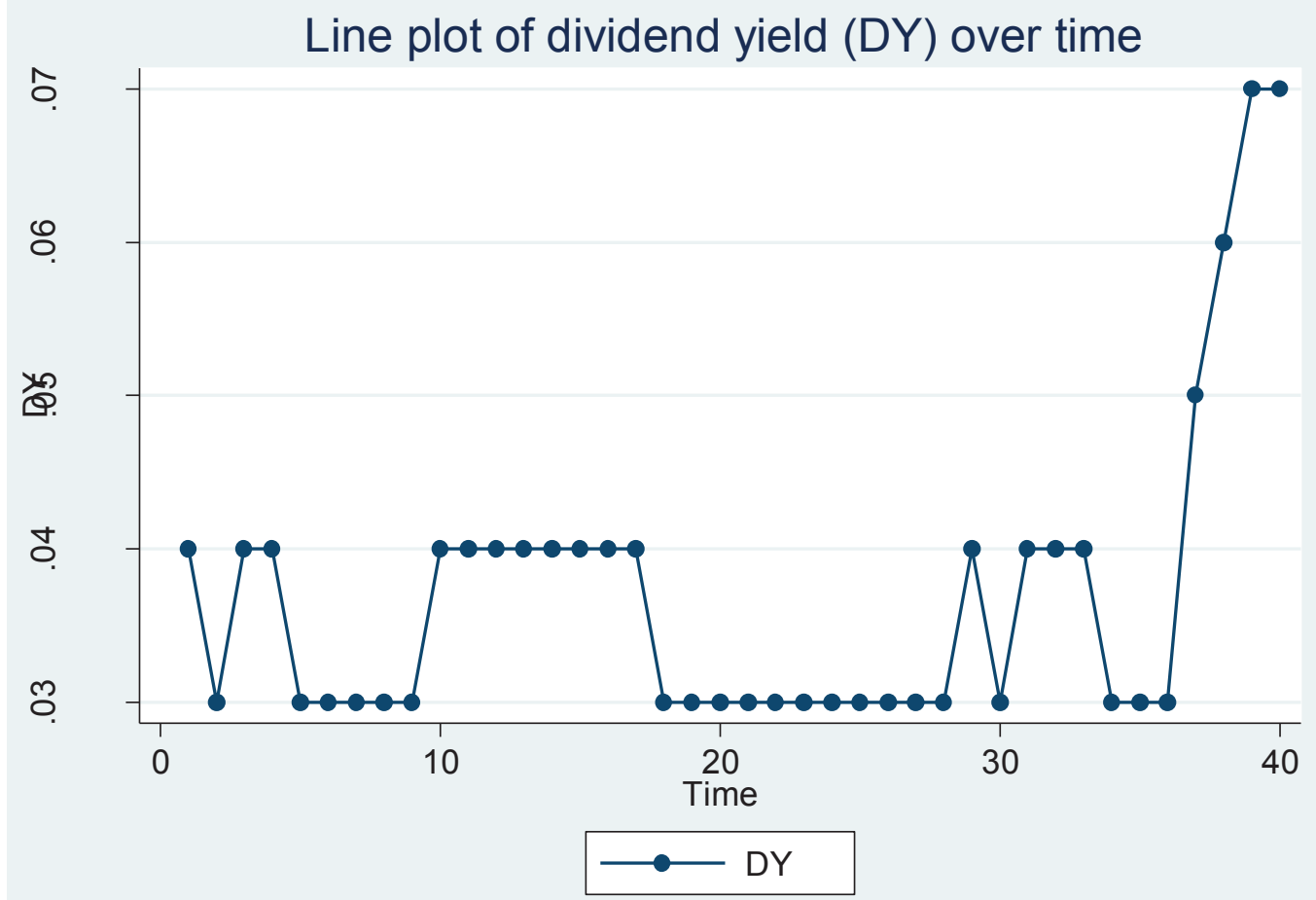

Figure 8: Graphical line plot of Dividend Yield over ten years period. Source: Field Data, 2019 


\subsection{Relationship Between Dividend yield and Stock Return in Nairobi Securities Exchange.}

Table 2: Relationship Between Dividend yield and Stock Return in Nairobi Securities Exchange.

\begin{tabular}{r|crc} 
Source & SS & df & MS \\
\hline Model & .04622715 & 1 & .04622715 \\
Residual & .201578883 & 37 & .005448078 \\
\hline Total & .247806034 & 38 & .006521211
\end{tabular}

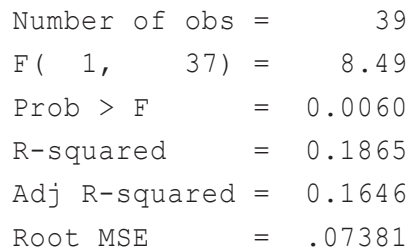

\begin{tabular}{r|rrrrrr}
\hline LAGNSE2 0SH X & Coef. & Std. Err. & $t$ & P > t I & [95\% Conf. Interval] \\
\hline LAGDY & -.3431285 & .1177958 & -2.91 & 0.006 & -.5818055 & -.1044515 \\
_COnS & -.0033839 & .0119148 & -0.28 & 0.778 & -.0275256 & .0207579 \\
\hline
\end{tabular}

From the findings in Table 2 coefficient of determination $\mathrm{R}^{2}=0.1865, \mathrm{~F}(1,37)=36, \mathrm{p}=0.006$. This shows that probability of variance in stock return that is explained by measures of dividend yield is $18.65 \%$ however $16.46 \%$ variation is stock return could be explained by independent variable. R- Squared however seems like an easy to understand statistic that indicate how well a regression model fits the data set. However, it does not tell us the entire story, to get a full picture; one must consider $\mathrm{R}^{2}$ value in combination with residual plots, other statistics and in-depth knowledge of the subject area (Dhakal, 2018).

According to Frost (2017), caveats about $\mathrm{R}^{2}$ are: - small R- squared values is not always a problem and high $\mathrm{R}$ - squared values are not necessarily good. For instance, for an outcome variable like human behavior, which is very hard to predict, a high value of $\mathrm{R}^{2}$ is almost impossible and this does not mean that any predicted model to such case is always useless. A good model can have a low R-squared value. On the other hand, a biased model can have a high $\mathrm{R}$ - squared. As $\mathrm{R}^{2}$ increases, the standard error will decrease (Dhakal, 2018). On average, estimates of NSE-20 Share Index with dividend yield with the model in Table 2 will be wrong by $11.78 \%$. Given that standard error is wished to be as small as possible, this standard error is small enough to be ignored. The final equation for the model in Table 2 will be given by:

NSE 20- SHARE INDEX t $^{=}=0.0033839-0.3431285(\mathrm{DY})_{\mathrm{t}} \ldots \ldots \ldots \ldots \ldots \ldots 1$

From equation 1, -0.3431285 change (negative) in dividend yield at time $t$ will lead to a corresponding change in NSE-20 Share Index at time $t$ by one unit .

Results in table 2 shows that dividend yield has negative significant relationship with stock performance $(\mathrm{t}=-2.91, \mathrm{p}=0.006)$. The results imply that when dividend yield increases, stock return decreases and when dividend yield decreases, stock return increases. The results in the present study confirm finance principles since dividend yield is given by cash dividend divided by market price per share. Increase in market price per share leads to decrease in dividend yield which consequently leads to increase in stock return. The results in the present study is consistent with Kamini \& Malhotra (2013) who asserted that dividend yield has a significant inverse association with market price of the firm's stock. Furthermore, results confirm observations by AlMasum (2014) who opined that there exists a significant negative relationship between dividend yield and stock price $(\mathrm{t}=-2.90, \mathrm{p}=0.005)$. However, in South Africa, Nicol (2013) revealed a contradicting results by observing that dividend yield influence returns positively. Nicol (2013) however had a unique methodological approach; his study covered 15 year period, his study included both listed and delisted firms in Johannesburg Securities Exchange. The reviewed studies however did not use time series analysis in their methodology, they did not use quarterly data and some of them were not done in Kenya hence, this may be the reason for mixed results.

\section{Conclusion}

Dividend yield has significant but inverse relationship with stock return. This means that when dividend yield increases, stock return reduces. The result here is justified since increase in dividend yield is due to increase in dividend payment leaving the firm with little retained earnings which in turn reduces stock return. Dividend yield is a ratio given by dividend income divided by income per share. The results here are consistent with most of empirical works reviewed in the present study. Dividend yield reflects the portion of a company's earning that is given to shareholders as dividends. Depending on the need or believes of investors, some investors would opt for re-investing their dividend proceeds so as to earn more income streams in form of capital gain while other investors will take the dividends. Whichever direction an investor may take, neither of them is safe, for instance a company may declare high dividends but its performance is poor. On the other hand a company may declare little dividend but its managers make good investment decisions with the retained earnings. In conclusion, investors should assess investment activities of a firm and its financial soundness before considering to reinvest 
dividend proceeds or to receive the proceeds as cash dividends.

\section{References}

Al-Masum, A 2014, Dividend policy and its impact on stock price- study on commercial banks listed in Dhaka Stock Exchange; Bangladesh. ). Dividend policy and its impact on stock price- study on com Global Disclosure of Economics and Business, 3 , 9-16

Bradley H \& Sean, L 2006, Encyclopedia of Measurement and Statistics. SAGE publications.

Chinelo I 2016, Fundamentals of research methodology and data collection. Lagos Nigeria: LAP Lambert Academic Nigeria.

Cooper, RL 1972, The Predictive Performance of Quarterly Econometric Models of the United States, Econometric Models of Cyclical Behaviou. New York: Bert G. Hickman,ed.

Creswel, J 1994, Quantitative, qualitative and mix methods approaches. California: Sage Publications, Inc.

Creswell, JW \& Clark, PV 2011, Designing and conducting mixed methods Research. London: Sage Publications Ltd.

Ebaid, IE 2009, The impact of capital structure choice on firm performance: empirical evidence from Egypt. The Journal of Risk Finance 10(5), , 477-487.

Frost, J 2017, How to interpret R-squared in regression analysis. Retrieved from http: //statisticsbyjim.com/regression/interpret-r squared-regression/ Accessed on 02 June 2018.

Granger, CW \& Newbold, P 1974, Spurious Regression in Econometrics. Journal of Econometrics, vol.2 (2), $111-120$.

Goles, T \& Hirschheim, R 2000, The paradgm is dead, the paradgm is dead..long live the paradgm: The legacy of Burrel and Morgan. Omega Vol. $28,249-268$.

Gujarati, DN 2006, Essentials of Econometrics, 3rd ed. New York: McGraw-Hill, New York .

Herman, A Sharon, N \& Bailey, JR 2019, Best practices in data collection and preparation: Recommendations for Reviewers, Editors, and Authors. Organizational Methods, 1-16.

Kamini, T 2013, Determinants of stock prices: Empirical Evidence from NSE 100 companies. International journal of Research in Management \& Technology, $\quad$ ISSN: Vol. 3 , 2249-9563.

KNBS, 2011,.Kenya Economic Report. Nairobi, Kenya. https://www.knbs.or.ke

KNBS, 2016, The Kenya Economic Survey. Nairobi: KNBS. https://www.knbs.or.ke

Kang, E Kim, R \& Sekyung, O 2019, Dividend Yield, Stock Returns and Reputation. ACRN Journal of Finance and Risk Perspectives, 8 , 95-105.

Maxcy, S, 2003,Pragmatic threads in mixed methods research in the social sciences:The search for multiple modes of inquiry and the end of the philosophy of formalism. Mixed methods in social and Behavioral research, 51-89.

Mugenda, O \& Mugenda, A 2003, Research Methods Quantitative and Qualitative Approaches. Nairobi: ACT.

Mlambo, C \& Biekpe, N 2001, Investment Basics XLIV: Review of African Stock. Munich Personal RePEC Archive (MPRA)

Nicol, E 2013, Dividend policy and wealth maximization: The effect of market movements on dividend investing returns. Published Masters of Commerce Thesis at the Faculty of Economics and Management Science, Stellenbosch University. Stellenbosch University.

Nunnaly, J 1978, Pysdiometric theory. New York: Hill Book Company. New York: Hill Company.

Phillips, D 1987, Validity in qualitative research, why the worry about warrant will not wane. Education and Urban Society 20(1), 9-24.

PWC, 2019, Capital Markets in 2030: The future of equity capital markets. London, UK: PWC.

Robson, C 1993, Real world research: a resource for social scientists and practitioner researchers. Cambridge, USA: Blakewell.

Saunders, M Lewis, P \& Thornhill, A 2007, Research methods for business students, 4th edition. London: Prentice Hall.

Smith, J 1983, "Quantitative verses Qualitative Research: An attempt to clarify the issue". Educational Researcher, 12(3) , 6-13.

Tashakkori, A \& Teddlie, C 1998, Mixed Methodology: combining Qualitative and Quantitative Approaches Vol.46. Oaks, CA: Sage Publications ..

Vibha, K. \& Walsh C 2019, Pragmatism as a research paradgm and its implications for social work research. Social Sciences .

Zeitun, R \& Tian, G 2007, Capital structure and corporate performance: Evidence from Jordan. Australian Accounting Business and Finance 1(4), 39-61.

Oberiri, D 2017, Quantitative Research methods a synopsis approach. Arabian Journal of Business and Management Review Vo.6(10), DOI: 10.12816/0040336. 